\title{
Managing Zakat through Institutions: Case of Malaysia
}

\section{Abdalrahman Migdad *}

Received: 29.01.2019

Accepted: 01.10.2019

DOI: $10.25272 /$ ijisef.519228

Type: Research Article

\begin{abstract}
Uniquely, zakat is featured as the major tool of Islamic wealth redistribution that routinely collects designated amounts of public money from zakat payers and channels same to identified beneficiaries in accordance with the principles of the shari'ah. It is, therefore, essential to organize and develop institutions to manage this wealth. This paper analyzes the Malaysian zakat system, assesses its performance by studying the collection and disbursement mechanisms. The paper is qualitative descriptive-analytical in nature, it analyzes annual reports and interviews with the higher management of ZCC and religious councils. The paper focuses on data between the year 1991 to 2014/15. This paper finds that the Malaysian experience with managing zakat advanced technically in both distribution and collection. However, the practice of 'distribution' ought to be more sustainable, less consumption-based. Furthermore, the paper strongly identifies the need for establishing a database on needy people with the national welfare system and other relief NGO's to reduce double spending.
\end{abstract}

Keywords: Zakat System, Sustainable Spending, Public Money

Jel Codes: H24, H70, I31

\footnotetext{
* İstanbul Sabahattin Zaim University, Faculty of Business and Management, abdmigdad@gmail.com, ORCID: https://orcid.org/0000-0001-8841-5363
} 


\section{Introduction}

The institution of Zakat in most countries does not have an official structure and lacks advanced circulation mechanisms for the pooled zakat money. However, Malaysia has developed a system for collecting and redistributing zakat through state-centralized institutions of zakat that are not exclusive to other institutions, set by individuals or organizations, that collect zakat. It is generally acknowledged that the Malaysian zakat system is advanced, and thus, it is usually benchmarked as a successful case worth studying and learning from.

Zakat Collection Center (ZCC) in each Malaysian state follows the state's religious council in charge of both collection and disbursement. There are clear guidance and specialists/consultants that support zakat payers to calculate their zakat in relation to their tax. The payment of zakat and payment of the tax affect each other in Malaysia and in some cases could be replacements in total or partial amounts. However, because the nature of each is different, the laws for each are different. Basically, tax is compulsory by law and while there is a law that could be used by the government to force payment of zakat, that is not the case Zakat being faith-based makes the religious commitment the only power that incentivizes payment of zakat in Malaysia and elsewhere. In Malaysia, this combination of relationships is also considered by zakat institutions. The paper illustrates data of collected zakat and collected tax up to the year 2015-2016, the idea is to compare numbers and show the pattern of growth in Zakat using graphs and tables.

Using basic mathematical logic, the amount of zakat collected could be estimated each year giving the basic fundamentals. In Malaysia, for instance, with a population of about 31 million, and with around $50 \%$ being Muslim, the zakat on the individual (Zakat-ul-Fitr) collected during the month of Ramadan is about 1.30 USD multiplied by 15.5 million persons would equal 20.15 million USD. As for zakat on wealth, (Zakat-ul-Maal), it is much larger than this amount. In the year 2016, the zakat collection in Malaysia was 2.5 billion RM, which is equivalent to about 598 million USD. ${ }^{1}$ According to this logic. Furthermore, it could be argued that the total amount of zakat collected in Malaysia could be more than the officially announced figure because not all people pay their zakat through the State Zakat Collection Centers (ZCC).

Managing the zakat money professionally by specialized institutions that are connected makes a difference and extends the benefits. Creating an efficient system of collection and disbursement filters management lacks and abuses such as overspending, management cost, and double payments from different institutions. However, because zakat is public money, related to faith, and needs to be spent in specific directions, there is need for transparency in order to gain public trust. In this paper, explaining the zakat system in Malaysia includes management and calculation methods, collection of zakat, and distribution mechanisms. The paper is qualitative descriptive-analytical in nature and seeks to provide an assessment of the

\footnotetext{
${ }^{1}$ The exchange from MYR to USD was made on 8/20/2019
} 
overall performance of the zakat institution in Malaysia by analyzing annual reports and interviewing with the higher management of ZCC and religious councils in the state of Malacca and Federal Territory of Kuala Lumpur. The paper is organized in five sections; after the introduction, the paper explores how zakat is managed, then, the collections of zakat followed by the distribution of zakat and finally concludes. Furthermore, the main purpose of the paper is to point out further potential of zakat if sustainable spending mechanisms are employed and consumption-based spending mechanisms are minimized.

\section{Management of Zakat}

The Malaysian institution of zakat is characterized by a number of distinctive features such as being social, independent, and not controlled/centralized in the hands of the federal government but state governments. There are 13 states in Malaysia, and 3 federal territories, each has a Sultan and a religious council which acts as the responsible body for collecting and disbursing zakat. (Figure 1) illustrates how the zakat is managed and shows the functions of the state's religious council. This illustration also shows the relationship between the federal government, the state Sultans, and the state religious councils. One may assume that the federal government may be on top of the hierarchy, but that is not the case. However, since zakat is public money, the national government's corruption agencies have the responsibility to review the records and financial statements of any religious council at any time. As for management, the federal government could cooperate, but the state Sultan is the highest authority when it comes to the management of the religious council that oversees the operations of zakat institution. 


\section{Figure 1: Zakat Management and Collection}

Zakat management is the responsibility of state through MAJLIS (religious council); that is, a constitutionally protected constitutional state right
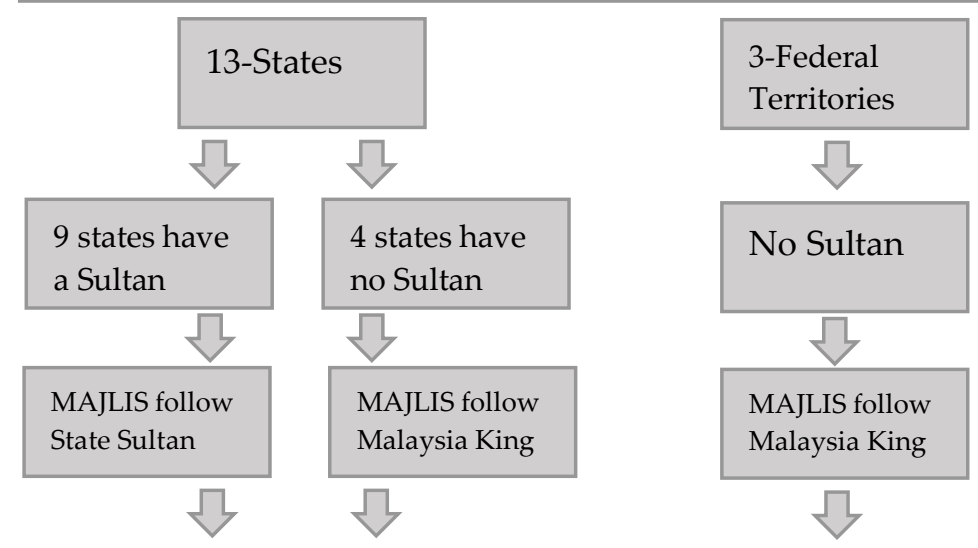

Collecting Zakat by the (14 MAJLIS)
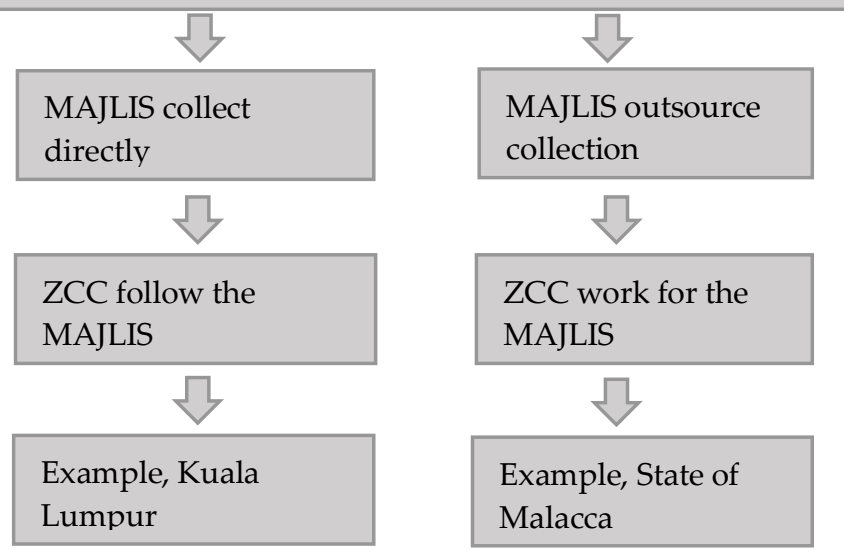

Federal government support States in management

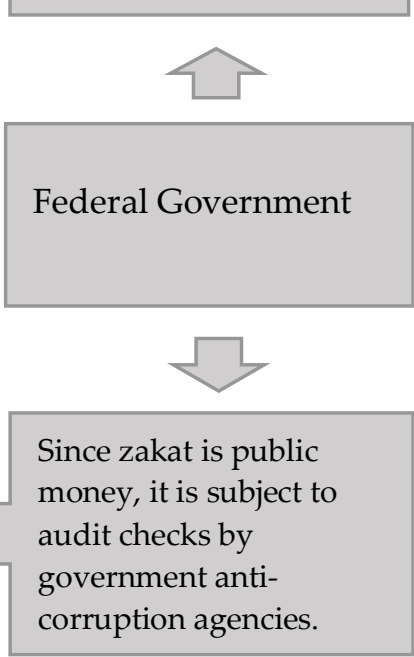
government anticorruption agencies.

Collection techniques

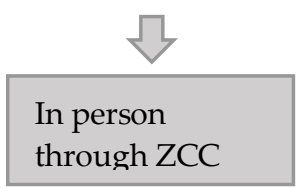

Electronically, salary deduction

Source: Author's Illustration

\subsection{Laws of Calculating Zakat in Malaysia}

According to the Malaysian Standards Board in their technical release i-1 (2006); titled: "Accounting for Zakat Business," indicates that zakat for the current period, the present time, shall be recognized when:

- " "an entity has a current zakat obligation as a result of a zakat assessment;"

- " an outflow of resources embodying economic benefits will be required to satisfy the zakat obligation;" 
- "The amount of zakat assessed shall be recognized as an expense in the period in which it is incurred;" and

- "When an entity pays zakat on its business assets, such amount of zakat is recognized as an expense and included in the income statement for the period in which it is incurred."

Assessment of zakat: "Zakat shall be assessed when the entity has been in operation for at least 12 lunar months, i.e., for the period known as "haul". Zakat on business shall be calculated by multiplying zakat rate with zakat base."

Zakat rate: "The rate of zakat on business, as determined by the National Fatwa Council, Malaysia is $2.5 \%$ of zakat base."

Zakat base: "Zakat base is the net adjusted amount of zakat assets and liabilities used for or derived from business activities. An entity is advised to refer to the relevant zakat authorities for further guidance in determining the net adjusted amount of zakat assets and liabilities."

\subsection{Modules for Calculating Zakat}

According to Abdul Wahab et al. (1995), there are three methods ${ }^{2}$ of business zakat accounting practiced in different states of Malaysia. Those modules are also recognized by the Malaysian Accounting Standards Board (2006).

- First: only current assets such as cash in hand or bank and accounts receivable. This is practiced by the Bait-al-Mal of Perak, Kedah, Wilayah Persekutuan, and other States.

- Second: current assets and profit from investment. Two institutions practice this method, i.e., Bait-al-Mal of Perlis and the Pilgrim Management Fund Board.

- Third: the difference between current assets and current liability, which is also called the networking capital method. This method is adopted by Bank Islam Malaysia Berhad.

The Department of Islamic Development Malaysia published Malaysia Zakat Guide in the year 2001. According to this book, two business zakat accounting are highly recommended to use. First is the adjusted growth capital method, and the second is the working capital method (Hamat, 2009).

\section{Adjusted growth capital method:}

\section{Equity + Long-Term Equity - Fixed Asset - Non-Current Asset + / - Adjustments}

\section{Adjusted working capital method:}

Current Asset - Current Liabilities + / - Adjustments

\footnotetext{
2 The three methods explained are widely used in Malaysia and online user-friendly zakat calculators are made available online by Islamic banks and other institutions and charities that accept zakat.
} 
The following equation demonstrates the difference between both method equations: Equity +tong Term Liabilities- Fixed Assets -'Noncurrent Assets = Current Asset - Current

\section{Liabilities}

Both methods generally conclude with the same result where the input is driven from the same balance sheet. However, most of the states in Malaysia use the adjusted working capital method, which is also known as the Shariya method (Hamat, 2009, p. 15). Presenting the most common methods of calculation, some adjustments relating to current assets and liabilities are necessary (Awang, 2011; Hamat, 2009).

Table 1: Current Assets Adjustments

\begin{tabular}{|c|c|}
\hline Current Assets (RM) & Explanation \\
\hline Work In Progress (W-I-P) & $\begin{array}{l}\text { W-I-P should be deducted from a net worth of current assets } \\
\text { since only finished goods are recognized as productive. }\end{array}$ \\
\hline Raw Material & $\begin{array}{l}\text { Raw material should also be deducted since only finished } \\
\text { goods are recognized as productive }\end{array}$ \\
\hline $\begin{array}{l}\text { Fixed Deposits with a } \\
\text { licensed } \\
\text { Collateralized }\end{array}$ & $\begin{array}{l}\text { Encumbered Fixed Deposits with a licensed bank is deducted } \\
\text { since it is not recognized as having full ownership. Normal } \\
\text { fixed deposits are subject for zakat. }\end{array}$ \\
\hline Interest on Fixed Deposit & Non-halal source of Income should be deducted. \\
\hline Charity kind of fund & $\begin{array}{l}\text { Fund formed for charity purposes; i.e., for education and } \\
\text { 'khairat' contained in assets should be excluded from zakat. }\end{array}$ \\
\hline Dividend & $\begin{array}{l}\text { The dividend which was paid by an investment company will } \\
\text { be deducted from the net worth of current assets (if the } \\
\text { dividend has been assessed earlier for zakat before being } \\
\text { distributed) since zakat is not charged twice in the same period } \\
\text { (haul). }\end{array}$ \\
\hline Donation & $\begin{array}{l}\text { Donation made by a company at the end of the accounting } \\
\text { period (haul) needs to be re-added (assessed for zakat) since the } \\
\text { donation will not affect the company's liquidity unless the } \\
\text { donation is taken from the charity fund. }\end{array}$ \\
\hline
\end{tabular}

Source: (Awang, 2011) 
Table 2: Current Liabilities Adjustments

\begin{tabular}{|c|c|}
\hline Liabilities & Explanation \\
\hline Hire Purchase & $\begin{array}{l}\text { Need to be re-added because it is recognized as a source of } \\
\text { business, having full ownership thus not allowable for deduction. }\end{array}$ \\
\hline Bank Borrowings & $\begin{array}{l}\text { Need to be re-added since it is a source of fund and recognized } \\
\text { as full ownership. }\end{array}$ \\
\hline Dividend payable & $\begin{array}{l}\text { Need to be re-added since it is a business profit which needs to } \\
\text { be assessed for zakat first before it is distributed to shareholders. }\end{array}$ \\
\hline Trade loans & $\begin{array}{l}\text { Need to be re-added since the loan is classified as a source. Iman } \\
\text { Syafie (one of the Islamic Scholars) argued that a loan tantamount } \\
\text { to having full ownership. }\end{array}$ \\
\hline
\end{tabular}

Source: (Awang, 2011)

\subsection{Zakat Connection to Tax}

Both zakat and tax are public money, the first is required by Islam but not enforced by the Malaysian law, the second required by the Malaysian law and is compulsory. Table 3 illustrates the differences in value between the two which is enormous. Additionally, Figure 2 presents a graphical illustration of the same relationship that helps to visualize the difference in value.

The philosophical view is more or less money in the hands of the government with complete or limited freedom to spend in any direction. This presented analyses can only exist implicitly, no judgment is imposed on intentions, but for the sake of clarifying possible linkages that connect loose ends, this implicit analysis is presented. The meaning of "freedom to spend" is that the government can spend tax however it needs and desires. However, if the government is the entity collecting zakat, spending will be restricted to eight different directions only. 
Table 3: Value of Zakat V. Value of Tax 1991 - 2014 (Million MYR)

\begin{tabular}{|c|c|c|c|c|c|}
\hline Year & Zakat Malaysia & Tax revenue & Year & Zakat Malaysia & Tax revenue \\
\hline $\mathbf{1 9 9 1}$ & 61 & 30596 & $\mathbf{2 0 0 3}$ & 408 & 78902 \\
\hline $\mathbf{1 9 9 2}$ & 76 & 34381 & $\mathbf{2 0 0 4}$ & 473 & 87563 \\
\hline $\mathbf{1 9 9 3}$ & 92 & 39780 & $\mathbf{2 0 0 5}$ & 573 & 93932 \\
\hline $\mathbf{1 9 9 4}$ & 110 & 44240 & $\mathbf{2 0 0 6}$ & 671 & 102668 \\
\hline $\mathbf{1 9 9 5}$ & 122 & 50134 & $\mathbf{2 0 0 7}$ & 806 & 120909 \\
\hline $\mathbf{1 9 9 6}$ & 159 & 56905 & $\mathbf{2 0 0 8}$ & 1038 & 114754 \\
\hline $\mathbf{1 9 9 7}$ & 202 & 48765 & $\mathbf{2 0 0 9}$ & 1197 & 118302 \\
\hline $\mathbf{1 9 9 8}$ & 198 & 48874 & $\mathbf{2 0 1 0}$ & 1364 & 144297 \\
\hline $\mathbf{1 9 9 9}$ & 196 & 51857 & $\mathbf{2 0 1 1}$ & 1639 & 161539 \\
\hline $\mathbf{2 0 0 0}$ & 259 & 6601 & $\mathbf{2 0 1 2}$ & 1933 & 166269 \\
\hline $\mathbf{2 0 0 1}$ & 320 & 72241 & $\mathbf{2 0 1 3}$ & 2265 & 2457 \\
\hline
\end{tabular}

Source: Tax data: Department of Statistics Malaysia, Official Portal, Time series data (2017);

Zakat data: until 2012 (PPZ MAIWP, 92-2016), after 2013 (JAWHAR, 2017)

The federal government revenue comes from several sources. Of the important sources are corporate income tax, individual income tax, Goods and Services Tax (GST), oil-related revenue, the share of oil-related revenue, in addition to other sources. The tax revenue represents approximately two-third of the total government revenue according to the Ministry of Finance and as contained in the Central Bank's 2016 annual report (Bank Negara Malaysia ,2017, p. 83; Ministry of Finance Malaysia, 2017, pp. 79-80).

The zakat payment to any state MAJLIS through any ZCC is tax deductible. Individual zakat paid could result in making tax reach zero. With regard to corporate zakat, "based on the Malaysian Income Tax Act (Section 44 (11A)), Zakat paid by a corporation is claimable, and the amount eligible for claim is restricted to $2.5 \%$ of the Aggregate Income reported to the 
Inland Revenue Board. Hence, yes it will reduce the amount of chargeable income and tax payable." ${ }^{\prime 3}$

Figure 2: Value of Zakat V. Value of Tax 1991 - 2014 (Million MYR)

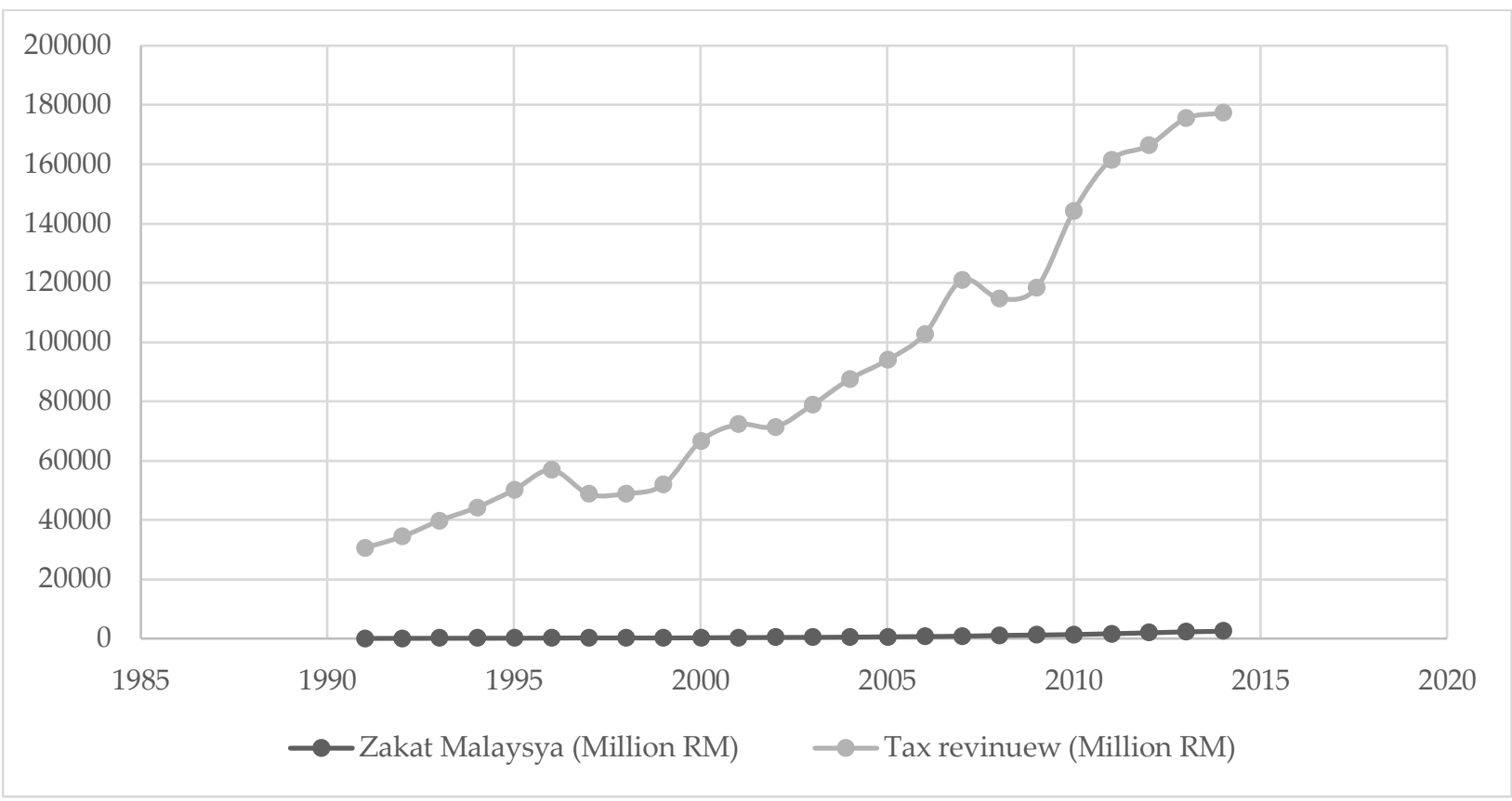

Source: Author Illustration

Data source: Tax data: Department of Statistics Malaysia, Official Portal, Time series data (2017);

Zakat data: (PPZ MAIWP, 92-2016)

The overly broad difference must have some indications. These include but not limited to the following reasons; First, only half of the Malaysian population is Muslim and not all of the Muslim business owners pay zakat. Second, State Owned Enterprises (SOE) also do not pay zakat, and considering the fact they are the largest enterprises in the nations makes a more significant difference.

\subsection{Corporate Zakat V. Tax in Malaysia}

Zakat on wealth is similar to the income tax paid annually to the national government in most countries of the world. However, zakat is on wealth and tax is on income. Zakat is a fixed 2.5\% of one's wealth, but income tax could range from $5 \%$ to $45 \%$ of income. Concentrating the comparison between corporate zakat only and tax is because the first type of zakat (zakat alfitr) is a symbolic amount of money that is obligatory on all Muslims, as for zakat on wealth (zakat al-maal) it's not an obligation on all Muslims, only on those who possess wealth that exceeds a certain threshold as discussed earlier (called nesab).

\footnotetext{
${ }^{3}$ This information was provided by the tax specialists at Khazanah as requited during the interview.
} 


\section{Bank Islam Malaysia zakat example}

"In the financial year, the Bank has fulfilled its obligation to pay zakat on its business to State zakat authorities by adopting the growth capital computation method and in compliance with the Manual Pengurusan Zakat Perbankan issued by Jabatan Wakaf, Zakat dan Haji. The Bank paid the Zakat on its portion, i.e., shareholders' fund as well as other funds received by the Bank except for depositors' fund."

"Several zakat authorities had refunded a portion of the zakat paid for the Bank to act as their agent (wakil) to distribute to eligible beneficiaries (asnaf) among needy individuals, mosque, non-governmental organizations, higher learning institutions (needy student's welfare funds) and schools as guided by the Business Zakat Payment Guideline that was approved by us."

Table 4: Bank Islam Malaysia 2015 - 2016 Zakat and Taxation

\begin{tabular}{|l|l|l|}
\hline & $2016(, 000)$ & $2015(\mathbf{0 0 0 )}$ \\
\hline Profit before zakat and tax & 720,441 & 685,131 \\
\hline Zakat and taxation & 45,019 & 25,587 \\
\hline Zakat & 12,851 & 8,711 \\
\hline Taxation & 32,168 & 16,876 \\
\hline
\end{tabular}

Source: (Bank Islam Malaysia , 2017)

\section{Collection of Zakat}

Although the collection of zakat is straightforward and unified among all Muslims, the legal system makes a difference. Despite Malaysia being constitutionally Islamic, practically it has a secular economic system. Law does not enforce religious practices, and the federal government tries to stand on the middle-ground to achieve an equilibrium that may leave some people unsatisfied but will achieve the common goal of development. The illustrated sources of zakat in Figure 3 are clear, but dues from each are not necessarily collected completely because that will only depend on the desire of the owner. In contrast, the tax is compulsory for all. Although zakat is tax deductible as explained earlier, not all Muslims pay. That would indicate mainly either of two issues or both; that the person does not care about Islamic teachings, or does not understand how the calculation works. This is particularly true with regard to zakat on wealth when it involves something other than income, saving, and gold because the calculation is more straightforward. 
Figure 3: Types of Zakat

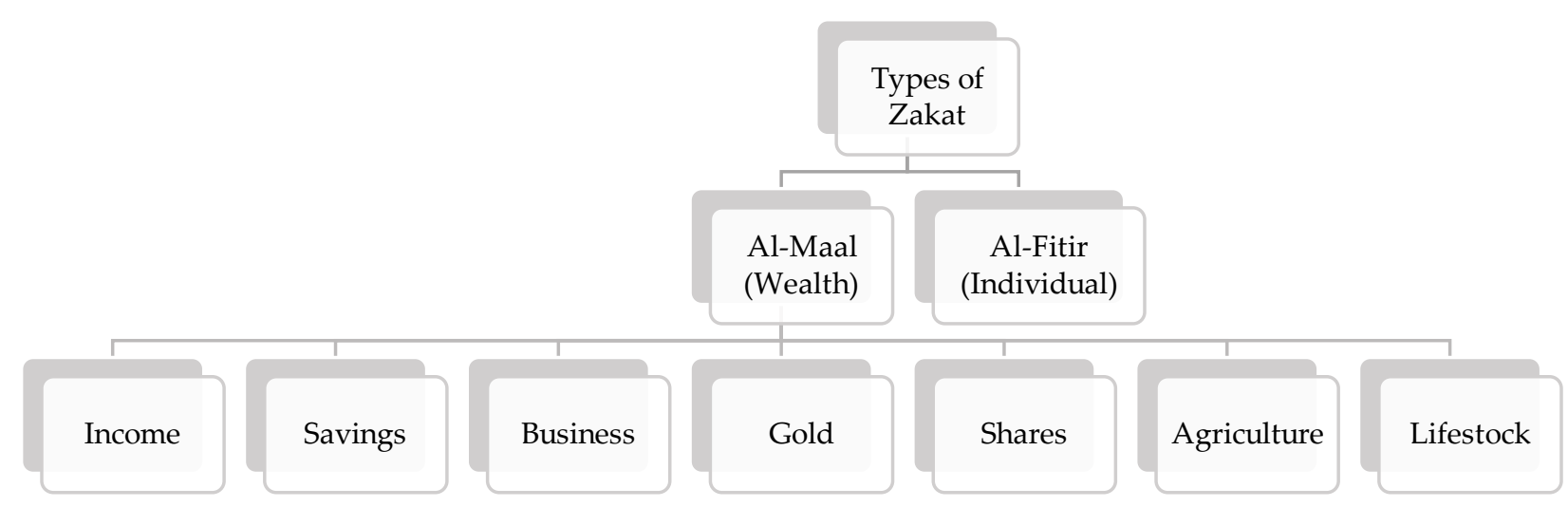

Source: Author's Illustration

\subsection{Value of Zakat Collection in Malaysia}

During the year 2016, Malaysia collected 2.5 billion MYR the equivalent of 598 million USD ${ }^{4}$ in zakat money. This 2.5 billion RM is collected mostly from businesses, not individuals. "The individual zakat paid does not even represent $10 \%$ of the total zakat, the majority is paid by large businesses and corporations." 5

In Malaysia, the individual-zakat is about 1.30 USD multiplied by $15.5^{6}$ million would equal 20.15 million USD. As for Zakat al Maal, it is much larger than that number, and both types of zakat are annually collected and disbursed only in eight specified social directions. Considering the 2016 zakat collection in Malaysia was 2.5 billion RM, the zakat on wealth is about 30 times more than the zakat on the individual collected during the month of Ramadan. Furthermore, logically the case could be made that the zakat collected in Malaysia is more than the officially announced number because not all people pay their zakat through the state ZCC as the findings of chapter 5 conclude.

\footnotetext{
${ }^{4}$ The exchange from MYR to USD was made on 8/20/2019

${ }^{5}$ Buhrawa, S. (2017, 15 May) Personal Interview, ISRA Head of research unit. However, Petronas does not pay zakat, those large SOE do not pay zakat, but have large CSR budgets that according to the interview with a financial investment manager of Khzanah, this charity payed by SOE would exceed the value of zakat if zakat was to be paid.

6 This number represents about half of the Malaysian population, which is a rough estimation of the Muslims in the country.
} 
Table 5: Value of Zakat in Malaysia

\begin{tabular}{|l|l|l|l|}
\hline Category & Malaysia & Kuala Lumpur & Malacca \\
\hline Size & $330,800 \mathrm{~km}^{2}$ & $243 \mathrm{~km}^{2}$ & Area: $277 \mathrm{~km}^{2}$ \\
\hline Population & 30.33 million $* * *$ & 1.73 million* & 873 thousand *** \\
\hline Zakat collected & 2.5 billion RM & 566 million RM* & 70.5 million* \\
\hline Beneficiaries & -- & -- & 14 thousand \\
\hline Covering need & Shortage of coverage & Shortage of coverage & Full coverage \\
\hline Per individual contribution & $6.7 \mathrm{RM}$ & $49 \mathrm{RM}$ & $12 \mathrm{RM}$ \\
\hline
\end{tabular}

*2016 estimation **2010 estimation ***2015 estimation

Data source: Department of Statistics Malaysia, Official Portal; Zakat data: (PPZ MAIWP, 92-2016)

The illustration in Table 5 showing the value of zakat in Malaysia and showcasing two examples; Kuala Lumpur and the state of Malacca is interesting for a number of reasons. 1) The economic situation and average cost of living are reflected. Kuala Lumpur has one of the highest costs of living, and the state of Malacca represents the general average in terms of the cost of living in Malaysia. 2) The interviews conducted by the author with both ZCC's revealed that despite the collection in Kuala Lumpur is highest or second in the list after the state of Selangor sometimes, it cannot cover all the demands of those entitled to receiving zakat, as for the state of Malacca it could. ${ }^{7}$ 3). Those numbers showing the individual contribution are not the only charitable financial contributions in the country. There are still waqf contributions, charitable contributions collected by tens of different NGOs, some of which also accept zakat money. Additionally, there are non-religious charitable contributions, such as 200 million MYR into one project in 2015 and 2016 just by Khazanah. ${ }^{8}$

\subsection{The Case of Malacca}

The case of Malacca is compelling because it falls in the middle and overall represents an average level of income and economic activities. Furthermore, the state has a successful record in managing, collecting and distributing zakat. (Table 6) shows the different types of zakat that would represent different percentages of the total number based on the economic activities of

\footnotetext{
7 This information relates to the year 2015 and 2016.

8 Sulaiman, H. (2018, 20 February) Personal Interview, Khazanah/ Mardi, M. (2018, 20 February) Personal Interview, Khazanah. This money is managed by Yayasan AMIR serving the development of education for all Malaysian Children in Public Schools. The director also indicated that more money could have been collected for that cause through "Sukuk Ihsan" but the capacity of their partner does not allow.
} 
the state. According to the $\mathrm{ZCC}^{9}$ manager ${ }^{10}$, as far as the numbers show, all Muslims in the state pay their zakat. He explained that due to the smaller size and the average-level cost of living the state enjoys, they are able to cover all the needs of people entitled to zakat support.

Table 6: Zakat Collection in The State of Malacca 2013-2016 (Million MYR)

\begin{tabular}{|c|c|c|c|c|}
\hline Type of Zakat & 2013 & 2014 & 2015 & 2016 \\
\hline Income & 25.1 & 30.4 & 35.2 & 39.6 \\
\hline Savings & 9.7 & 11.1 & 12.3 & 13.1 \\
\hline Business & 13.1 & 11.1 & 12.4 & 12.3 \\
\hline Gold & .5 & .5 & .7 & .7 \\
\hline Shares & 1.2 & 1.4 & 1.6 & .8 \\
\hline Life-stock & .08 & .07 & .1 & .08 \\
\hline Agriculture & .06 & .08 & .06 & .08 \\
\hline Zakat Al-Maal Total & 49.8 & 54,7 & 62.3 & 66.8 \\
\hline Zakat Al-Fitir & 3.3 & 3.6 & 3.6 & 3.7 \\
\hline Zakat Total & 53.1 & 58.2 & 66 & 70.5 \\
\hline
\end{tabular}

Data Source: ZCC of Malacca11

* The summation may not count up precisely as the numbers were rounded up

Table 6 shows total zakat collections from various sources in Malacca State. The sources that relate to economic and financial operations such as shares, business, and agriculture show fluctuation in the pattern of money collected each year. On the other hand, if we look at zakat al-Fitr, it is only connected to the increase in population; and the Malay population is increasing at higher rates than other ethnicities in Malaysia.

While the state of Malacca may be considered a successful case, it certainly has better potential to unfold. This yet-to-be-reached potential will ensure more sustainability and better resilience, but it requires enhancing the performance of managers in economics and investment. Similar to other states, Malacca disburses the money of zakat in small monthly stipend to ensure subsistence of families. The State's religious councils should focus on

\footnotetext{
${ }^{9}$ In the state of Malacca, the collection of zakat is outsourced by the states Religious Council.

${ }_{10}$ Pengarah, Z. (2017, 17 May) Personal Interview, ZCC Melaka

${ }^{11}$ This data was collected from the ZCC of Malacca during the researcher field visit 2017, however, this data is also available on line.
} 
developing profitable businesses to allow beneficiaries to take control of their lives and feel the dignity associated with self-reliance and independence, or in other words, to be free from want.

\section{Distribution of Zakat}

There are eight categories of people entitled to receive zakat as stipulated in the Quran (Q; AlTawbah: 60): The poor, vulnerable (the needy), service providers, people whose hearts are to be reconciled, freeing captives or slaves, the person in debt, for the sake of Allah, and for the traveler. The researcher does not intend to explore the reasons why the list is limited to those eight categories or the possibilities of expanding the range of beneficiaries as this is the work of Islamic fiqh scholars.

\subsection{Consumption v. Sustainability}

The criticism of performance connected to the Malaysian Religious Councils in managing zakat is directed to the way this money is distributed when it could be better utilized and invested. Spending zakat should ensure the sustainability of that money and thus ensure the economic well-being of those entitled to zakat support. From a different angle, the criticism points to the means by which entitled individuals could benefit. For example, much of the zakat money in KL and Malacca is spent in the form of monthly allowance at the subsistence level. A better way for the zakat money to be spent on those entitled is by training and positioning those entitled to receiving zakat in productive projects. The logic of the critics to the current management style stipulate that beneficiaries could receive zakat once or twice in larger chunks of money that would allow them to open a profitable project with some professional assistance, which would likely mean to uplift poor people above the poverty thresholds.

The delivery of zakat money should depend on the general status of the receiver. Meaning; the receiver is to be investigated, strengths and weaknesses are to be recognized, and the best mean of money delivery that ensures sustainability is to be utilized. Handouts, monthly allowance, and regular coupons, which are current practices, are only meant to specific groups of zakat-entitled individuals. Zakat entitlement could be received through opening a business for the beneficiary if they have a particular skill. The goal of zakat is to end any insecurity that entitled-individuals face while ensuring dignity and sustainability. Dignity could be ensured by making an individual free from needing the continued support from the zakat institution. Consequently, sustainability can be ensured by supporting a profit-generating start-up, or businesses.

As indicated, there are eight specific categories and all are humanitarian. This could be one reason why state MAJLIS adopts a consumption-based mechanism in handing out zakat. Food, shelter, education, and refugee support are among the typical practices of state MAJLIS in distributing zakat. The month of Ramadhan is a high season in spending zakat money; lots of that money is designated for Iftar (food for breaking the fast). The two days of Eid al Fitr and the 3-4 days of Eid Al-Adha are also seasons of high zakat expenditure. During such times food, 
shelter improvement, and clothing are primarily distributed. The annual reports of all state MAJLIS are full of pictures and events with details of money spent as well as places and numbers of people benefited.

Another method through which sustainability would be enhances is the establishment of a nationwide database for needy people and organizations that give support at the Federal and State levels. When asking about the possibility of one person benefiting from two different states as well as the national welfare system, that scenario was confirmed and indeed happened ${ }^{12}$. Personnel of the higher management at KL MAIWP explained that a nationwide database that serves to detect those who benefit from different institutions at the national and state levels do not exist.

\section{Conclusion}

Advancing both managerial and financial systems in institutions is a way to make noticeable change. Malaysia has been successful in institutionalizing zakat and benefiting from technology to facilitate calculation of zakat, payment of zakat, and also gave the options of paying by monthly installments. With regard to building trust, certain states, especially Selangor and Kuala Lumpur have also established online accessibility to zakat money collected and disbursed. That gives people the opportunity to track and monitor the process of collection and disbursement of zakat. Furthermore, there are annual reports that explain details and show where and how zakat was spent. Up to this point, the Malaysian experience could be of great benefit to others, however, more could still be done.

One potential advancement would be to establish a nationwide database that includes data from all Malaysian states. The goal of such database would be to list state-based zakat and charitable institutions with the federal welfare system. The database would also include beneficiaries of state or federal support systems that include zakat, welfare, and chartable NGO's. the goal is to detect individuals that benefit from more than one institution beyond their need; that would give a chance for more people to benefit. Establishing such a database would increase cooperation between states governments and the national government.

Through institutions, the collected zakat each year could be directed to specified causes. For example, the majority of zakat collected this year will be spent on poor people under a given threshold, or for refugees, or for people in debt, or for students from poor families. Such focus makes the effect of zakat money recognizable and serves as a clear demonstration for the success of the employed distribution strategies of sustainability.

12 Saiful (2017, 23 May) Personal Interview, MAIWP KL 


\section{References}

Abdul Wahab, M., Al-Junaid, A., Omar, M., Ghazali, A., Osman, J., \& Arif, M. (1995). Malaysia. Institutional Framework of Zakah: Dimensions and Implications (pp. 297 - 378). Jeddah: Islamic Development Bank.

Awang, R. (2011). Technical Comparison between Business Zakat and Tax on Business income in Malaysia. Malaysian Accounting Review, Vol. 10(No. 2), 13-25. Retrieved from http://ari.uitm.edu.my/main/images/MAR/vol10-2/chap2.pdf

Bank Islam Malaysia. (2017). 2016 Anual Report.

Bank Negara Malaysia. (2017). anual 2016 report. Bank Negara Malaysia.

BNM. (2017). publications. Retrieved 8 10, 2017, from http://www.bnm.gov.my/index.php?ch=en_publication\&pg=en_msb\&ac=246\&lang=en $\& u c=2$

Commission on Human Security. (2003). Human Security Now. New York: Commission on Human Security.

Hamat, Z. (2009). Business Zakat Accounting and Taxation in Malaysia. Conference on Islamic Perspectives on Management and Finance (pp. 13-18). leicester: School of Management, University of leicester. Retrieved from https://core.ac.uk/download/pdf/11966303.pdf

JAWHAR. (2017). Statistik Kutipan Zakat Seluruh Malaysia. Retrieved 3 2018, 8, from http://intranet.jawhar.gov.my/spmj/public/zkt_statistik_stat.php

Lombardi, M., Mohanty, M., \& Shim, I. (2017). BIS Working Papers No 607. The Teal Effects of Household Debt in the Short and Long Run. Retrieved from https://www.bis.org/publ/work607.pdf

Malaysian Accounting Standards Board. (2006). Technical Release i -1. Accounting for Zakat on Business.

Retrieved

from

http://www.masb.org.my/pdf.php?pdf=Accounting\%20for\%20Zakat\%20TRi-

1.pdf\&file_path=uploadfile

Ministry of Finance Malaysia. (2017). 2017 Economic Report. Ministry of Finance Malaysia. Retrieved from http://www.treasury.gov.my/pdf/economy/er/1617/chapter4.pdf

Petronas. (2016). Annual Report 2016. Retrieved from http://www.petronas.com.my/investorrelations/Documents/annual-report/PETRONASAnnualReport2016.pdf

PPZ MAIWP. (92-2016). BUKU LAPORAN. Retrieved from http://www.zakat.com.my/infoppz/laporan/buku-laporan/

PWC. (2015). State-Owned Enterprises Catalysts for public value creation? Retrieved from https://www.pwc.com/gx/en/psrc/publications/assets/pwc-state-owned-enterprisepsrc.pdf 
Abdalrahman Migdad

Sen, A. (2000). Development as Freedom. New York: Anchor Books. 